\title{
Pengembangan E-Modul Pembelajaran Berbasis Sigil pada Materi Induksi Matematika
}

\author{
Martina Ula ${ }^{1}$, Ganjar Susilo ${ }^{2 *}$, \& Besse Intan Permatasari ${ }^{3}$ \\ 1,2,3 Universitas Balikpapan, Balikpapan, Indonesia
}

\section{INFO ARTICLES}

Article History:

Received: 01-11-2021

Revised: 23-11-2021

Approved: 13-12-2021

Publish Online: 31-12-2021

Key Words:

Development; $\quad$ Mathematics

Learning E-module; Sigil;

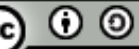

This article is licensed

under a Creative Commons AttributionShareAlike 4.0 International License.

\begin{abstract}
The purpose of this study was to determine the validity, practicality, and effectiveness of the sigil-based e-mathematical learning module on mathematical induction material. The research model is Research and Development Borg and Gall. Research data comes from teachers, students, librarians, books, and the latest journals. Data collection techniques are observation, interviews, questionnaires (questionnaires), documentation and tests. The data analysis technique used qualitative and quantitative analysis. The results showed that the material expert validation obtained a score of 3.39 and the media was 3.27 with the "Very Valid" criteria. In assessing the practicality of the sigil-based e-module, the teacher's response scored 3.57 and students 3.43 with the criteria of "Very Practical". While the effectiveness of the e-module obtained the qualification "Effective" with a percentage score of $82 \%$. Thus, the sigil-based e-module on mathematical induction material is valid, practical, and effective for use by students
\end{abstract}

\begin{abstract}
Abstrak: Tujuan dari penelitian ini untuk mengetahui kevalidan, kepraktisan dan keefektifan dari e-modul pembelajaran matematika berbasis sigil pada materi induksi matematika. Model penelitian ini ialah Research and Development Borg and Gall. Data penelitian berasal dari guru, siswa, pustakawan, buku-buku dan jurnal-jurnal terbaru. Teknik pengumpulan data yaitu observasi, wawancara, angket (kuesioner), dokumentasi dan tes. Teknik analisis data menggunakan analisis kualitatif dan kuantitatif. Hasil penelitian menunjukkan bahwa validasi ahli materi memperoleh skor 3,39 dan media 3,27 dengan kriteria "Sangat Valid". Dalam menilai kepraktisan e-modul berbasis sigil respon guru mendapatkan skor 3,57 dan siswa 3,43 dengan kriteria "Sangat Praktis". Sedangkan Keefektifan e-modul memperoleh kualifikasi "Efektif" dengan persentase skor 82\%. Dengan demikian e-modul berbasis sigil pada materi induksi matematika telah valid, praktis dan efektif untuk digunakan oleh siswa.
\end{abstract}

Correspondence Address: Universitas Balikpapan. Jalan Pupuk Raya, Kelurahan Gunung Bahagia, Balikpapan Selatan, Kalimantan Timur, Indonesia, Kode Pos 76114; e-mail: ganjar.susilo@uniba-bpn.ac.id

How to Cite (APA $6^{\text {th }}$ Style): Ula, M., Susilo, G., \& Permatasari, B.I. (2021). Pengembangan E-Modul Pembelajaran Berbasis Sigil pada Materi Induksi Matematika. JKPM (Jurnal Kajian Pendidikan Matematika), 7(1): 1-14. http://dx.doi.org/10.30998/jkpm.v7i1.11286

Copyright: 2021 Martina Ula, Ganjar Susilo, Besse Intan Permatasari

Competing Interests Disclosures: The authors declare that they have no significant competing financial, professional or personal interests that might have influenced the performance or presentation of the work described in this manuscript. 


\section{PENDAHULUAN}

Pada saat ini di seluruh dunia sedang terjadi wabah Coronavirus atau Covid-19. Coronavirus adalah virus yang dapat menyebabkan penyakit, mulai dari gejala ringan sampai dengan berat. Virus ini juga berdampak di dunia pendidikan saat ini terutama dari segi pengajaran guru dan pembelajaran di kelas. Proses belajar mengajar yang di sekolah berubah sangat signifikan dari yang berlajar di kelas menjadi belajar secara daring (online). Pembelajaran melalui daring merupakan suatu tuntutan bagi guru di saat pandemi Covid-19 dan di sisi lain menjadi terobosan baru dalam pembelajaran. Pembelajaran daring atau dalam jaringan mengakibatkan banyak pemikiran serta inovasi-inovasi baru menggunakan berbagai kecanggihan teknologi, dengan harapan nantinya akan membawa perubahan besar dalam dunia pendidikan dan mampu memberikan pengalaman belajar yang baru dan bermakna bagi siswa (Rustaman et. al., 2019). Selain itu, siswa juga memiliki banyak waktu untuk belajar, dan proses pembelajaran dapat dilakukan kapanpun dan di manapun, melalui berbagai aplikasi seperti google classroom, video conference, telepon atau live chat, zoom maupun melalui whatsapp group (Istikomah et. al., 2020).

Pembelajaran dalam jaringan (daring) adalah proses belajar mengajar dalam jangkauan luas dengan menggunakan berbagai macam kecanggihan teknologi komunikasi dan informasi yang terus berkembang pesat hingga saat ini (Anawati et. al., 2020). Dengan menggunakan berbagai kecanggihan teknologi komunikasi dan informasi tersebut diharapkan dapat membantu siswa dalam memahami materi-materi yang diberikan secara efektif, produktif, interaktif serta memiliki lifeskill dari penggunaan teknologi (Nirfayanti \& Nurbaeti, 2019). Matematika dikenal sebagai ilmu dasar dan merupakan salah satu ilmu paling penting dalam upaya meningkatkan mutu pendidikan serta kehidupan bangsa, karena dapat melatih kemampuan berpikir kritis, logis, analitis dan sistematis dengan sistem pembelajaran terstruktur, terorganisasi, serta bertahap, artinya bahwa terdapat tingkatan antara materi satu dengan yang lainnya (Angga et. al., 2019; Mulyati \& Evendi, 2020; Widyastuti, 2015). Akan tetapi pada kenyataanya matematika sering disebut sebagai pelajaran sulit, membosankan dan bahkan menakutkan bagi siswa (Agustina \& Rusmana, 2019). Dengan adanya perkembangan teknologi komunikasi dan informasi yang terus berkembang pesat mampu memudahkan siswa dalam mengakses berbagai sumber belajar melalui jaringan internet (Sasmita, 2020; Wiratomo \& Mulyatna, 2020). Selain itu, adanya sumber belajar diharapkan dapat menunjang kemandirian siswa dalam belajar baik di dalam maupun di luar kelas (Rusydi, 2020; Mulyatna et. al., 2021).

Berdasarkan hasil observasi dan wawancara bersama dengan guru matematika kelas XI IPA di SMA Negeri 9 Balikpapan menyatakan bahwa selama pembelajaran daring guru hanya menggunakan video yang telah dibuat sebelumnya kemudian mengirimkannya ke dalam google classroom agar dapat ditonton oleh seluruh siswa, dan apabila siswa tidak paham dengan materi yang disampaikan melalui video tersebut dapat datang ke sekolah untuk secara langsung berdiskusi bersama dengan guru. Namun pada kenyataannya hanya segelintir siswa yang mau datang ke sekolah untuk bertanya serta berdiskusi secara langsung kepada guru terkait kesulitan-kesulitan dalam memahami materi yang diberikan. Selain itu, selama pembelajaran daring guru belum mampu mengembangkan e-modul maupun menggunakan aplikasi zoom. Hal tersebut dikarenakan guru mengalami kesulitan dalam menggunakan media pembelajaran berbasis electronic yaitu tentang bagaimana cara mengoperasikan aplikasi pembuat $e$-modul, serta masih banyaknya siswa yang tidak memiliki paket data internet, tempat tinggal tidak terjangkau oleh jaringan internet dan siswa yang masih harus berbagi ponsel bersama dengan adiknya juga menjadi salah satu faktor guru enggan menggunakan aplikasi zoom sebagai media pembelajaran. Guru juga mengatakan bahwa siswa tidak diwajibkan untuk meminjam buku karena jumlah buku yang ada di perpustakaan sekolah tidak cukup bagi seluruh siswa.

Selain melakukan wawancara bersama dengan guru, peneliti juga melakukan wawancara dengan pustakawan. Pustakawan sekolah menyebutkan bahwa selama masa pandemi Covid-19 ini hanya segelintir siswa yang mau datang ke perpustakaan sekolah untuk membaca serta meminjam buku. Selain itu jumlah 
buku yang ada tidak cukup bagi seluruh siswa juga menjadi alasan mengapa guru tidak mewajibkan siswanya untuk meminjam buku di perpustakaan sekolah. Hal tersebut sejalan dengan hasil wawancara bersama dengan siswa di mana mereka enggan untuk meminjam buku yang terdapat di perpustakaan sekolah dengan alasan malas serta jarak antara rumah dan sekolah yang cukup jauh. Siswa juga menyebutkan bahwa selama pembelajaran daring pada mata pelajaran matematika terdapat kendala salah satunya yaitu video yang diberikan oleh guru terkadang kurang jelas baik dari segi kualitas video dan juga suara. Kurang tanggapnya guru dalam menjawab pertanyaan siswa melalui media e-learning baik whatsapp grup serta google classroom juga menjadi kendala selama pembelajaran daring. Alasan siswa enggan datang ke sekolah untuk berdiskusi secara langsung dengan guru yaitu jarak antara rumah dan sekolah yang cukup jauh, sehingga tidak jarang siswa lebih memilih untuk mencari berbagai referensi dari internet serta media sosial lain melalui smartphone ataupun laptop yang siswa miliki dengan tujuan agar lebih memahami materi yang disampaikan oleh guru.

Berdasarkan permasalahan-permasalahan tersebut terdapat pula potensi-potensi seperti guru dan siswa yang telah terbiasa dalam menggunakan $e$-modul. Oleh karena itu peneliti ingin mengembangkannya dengan cara menggabungkan antara materi dengan video pembelajaran dalam satu modul yang dapat dibuka baik melalui komputer, laptop ataupun smartphone siswa. Oleh karena itu, peneliti memilih media pembelajaran berupa e-modul (electronic modul) dengan berbasis sigil. Peneliti memilih media pembelajaran dan sumber belajar tersebut karena sigil dinilai cocok untuk dijadikan sebagai alat bantu dalam mengembangkan $e$ modul ini di mana aplikasi tersebut dapat disisipkan gambar, video bahkan audio serta memiliki sifat sederhana, praktis dan dapat digunakan kapan dan di mana saja, selain itu $e$-modul dengan berbasis sigil ini bisa dibuka melalui komputer, laptop, tablet, bahkan smartphone.

Sigil ialah sebuah software editor untuk epub yang bersifat open source. Sigil bisa digunakan sebagai media pembelajaran interaktif yang dapat mengkonversi file word menjadi epub (elektronic publication). Dengan penggunaan aplikasi tersebut diharapkan dapat menarik minat dan motivasi siswa dalam belajar sehingga dapat meningkatkan hasil belajar serta menjadi alat bantu dalam memudahkan pembelajaran seperti pada saat ini, dikarenakan tidak hanya gambar atau teks aplikasi sigil ini juga dapat digunakan untuk menyisisipkan file, audio bahkan video guna memperindah tampilan pada e-modul (Tobing et. al., 2020). Sigil memiliki sifat yang sangatlah friendly serta didukung oleh banyak perangkat seperti komputer dan smartphone sehingga dapat dengan mudah diakses melalui google chrome dan plugin firefox, atau melalui android dengan menggunakan ideal reader, FBReaderO, iOS (ireader), blackberry playbook, sony reader, serta berbagai perangkat lain (Darma et. al., 2019). Dengan segala kemudahan yang terdapat dalam aplikasi sigil tersebut diharapkan dapat dijadikan sebagai salah satu solusi dari permasalahan dalam dunia pendidikan baik pembelajaran langsung maupun tidak langsung (daring).

Berdasarkan penelitian yang sudah dilakukan, diperoleh hasil bahwa pengembangan $e$-modul berbasis sigil sangatlah membantu siswa pada pelaksanaan praktikum perkuliahan dimana dalam $e$-modul tidak hanya terdapat teks dan gambar akan tetapi ada juga video yang mampu membuat siswa mudah untuk memahami serta me-review kembali materi dengan sangat baik (Rustaman et. al., 2019). Sedangkan pada hasil penelitian lainnya, menunjukkan bahwa $e$-modul berbantuan sigil dapat mengatasi kesulitan dan kejenuhan siswa dalam mempelajari matematika dengan pendekatan saintifik pada materi SPLDV kelas VIII (Aisy et. $a l ., 2020)$. Selanjutnya pada penelitiannya juga, memperlihatkan $e$-book pada mata pelajaran fisika dapat melatih kemampuan berpikir kritis siswa dengan bentuk yang sangatlah praktis. Selain itu, e-book fisika dengan berbasis sigi dapat diterima dengan sangat baik oleh siswa (Amalia \& Kustijono, 2017). Kemudian menurut hasil penelitian lain juga menyebutkan bahwa terdapat pengaruh antara investasi kelompok berbasis sigil dan tingkat motivasi belajar siswa terhadap hasil belajar pada mata pelajaran biologi (Wahyudi, 2019). Masih diperkuat lagi dengan penelitian yang menunjukkan bahwa media pembelajaran berbasis electronic publication (epub) valid untuk digunakan setelah melalui serangkaian pengujian, electronic publication 
(epub) pada program studi informatika di Universitas Hamzanwadi, untuk uji ahli materi dan media termasuk dalam kategori sangat baik, serta mendapat respon baik dari para responden (Wirasasmita \& Uska, 2017).

\section{METODE}

Model penelitian ini ialah Research and Development (R\&D). Research and Development merupakan suatu penelitian dan pengembangan yang bertujuan untuk dapat menghasilkan sebuah produk tertentu dengan melalui beberapa tahapan salah satunya uji coba produk dan revisi guna mencapai kualitas serta standar yang telah ditentukan (Kamal, 2020). Pada konteks lain, Research and Development merupakan penelitian dan pengembangan yang digunakan dalam mengembangkan sesuatu produk di bidang pendidikan yaitu bahan ajar, buku, media pembelajaran serta segala sesuatu yang mempunyai hubungan dengan pembelajaran (Faizin, 2020).

Prosedur yang digunakan, model penelitian dan pengembangan oleh Borg and Gall dimodifikasi Sugiyono, terdiri atas 10 tahapan (langkah) (Sugiyono, 2017: 298). Dalam penelitian ini hanya sampai tahap ke-7. Semua tahapan (langkah) penelitian yang ada bukan merupakan langkah baku yang wajib untuk diikuti secara keseluruhan. Setiap peneliti dapat memilih dan menentukan tahapan (langkah) yang paling tepat dan sesuai. Pertimbangannya berdasarkan keadaan lapangan selama proses pengembangan berlangsung. Penyederhanaan atau pembatasan dari 10 langkah menjadi 7 langkah, dikarenakan faktor kesamaan antara langkah yang satu dengan lainnya, keterbatasan tenaga, serta waktu (Sugiyono, 2017: 298).

Uji ahli produk pengembangan $e$-modul berbasis sigil yang sedang dikembangkan diujicobakan kepada siswa kelas XI IPA 1 dan 2 SMA Negeri 9 Balikpapan. Pelaksanaan uji coba $e$-modul dilakukan setelah rancangan awal telah selesai melalui proses validasi oleh para ahli media maupun materi. Uji ahli produk merupakan tahap penilaian bertujuan untuk mengetahui produk tersebut telah valid digunakan atau tidak dengan tetap mempertimbangkan kesesuaian antara produk dengan pengguna dalam menyelesaikan berbagai permasalahan pada materi induksi matematika. Tujuannya untuk mengetahui e-modul yang dihasilkan dapat mencapai tujuan pembelajaran yaitu agar siswa memiliki minat dalam belajar, termotivasi dan mampu belajar secara mandiri.

Desain e-modul yang dikembangkan dapat dikatakan cukup baik untuk diuji coba kepada siswa dan mampu menjadi sebuah acuan dalam proses pembelajaran, jika e-modul tersebut sudah melalui proses validasi yang dilakukan oleh ahli materi dan media. Uji coba $e$-modul dilakukan melalui dua tahapan yaitu uji coba kelompok kecil dan uji coba lapangan. Uji coba kelompok kecil dilakukan pada 10 orang siswa kelas XI IPA 1 SMA Negeri 9 Balikpapan. Setelah uji coba kelompok kecil selesai dan telah direvisi, dilanjutkan dengan uji coba lapangan kepada seluruh siswa kelas XI IPA 2 SMA Negeri 9 Balikpapan sebanyak 28 siswa. Uji coba ini dilakukan agar dapat menentukan keparaktisan dan keefektifan dari $e$-modul berbasis sigil pada materi induksi matematika. Masukan, saran serta kritik terkait kekurangan yang terdapat dirangkum dan dianalisis guna perbaikan serta dapat meningkatkan kualitas dari $e$-modul sehingga mampu mencapai target dan tujuan pembelajaran.

Teknik yang digunakan dalam penelitian ini antara lain observasi, wawancara, angket, tes dan dokumentasi. Instrumen kuesioner pada penelitian dan pengembangan ini digunakan untuk ahli media, materi, dan praktisi menggunakan skala Likert. Jika dalam kuesioner terdapat masukan, kritik dan saran yang membangun guna dilakukan perbaikan terhadap e-modul berbasis sigil yang dikembangkan, maka pendapat-pendapat tersebut dapat dijadikan sebagai bahan pertimbangkan untuk memperbaiki $e$-modul berbasis sigil agar menjadi lebih baik. Sebelum diberikan kepada para ahli terlebih dahulu dibuat kisi-kisi lembar penilaian 
Tabel 2. Hasil Validasi Ahli Materi Tahap 2

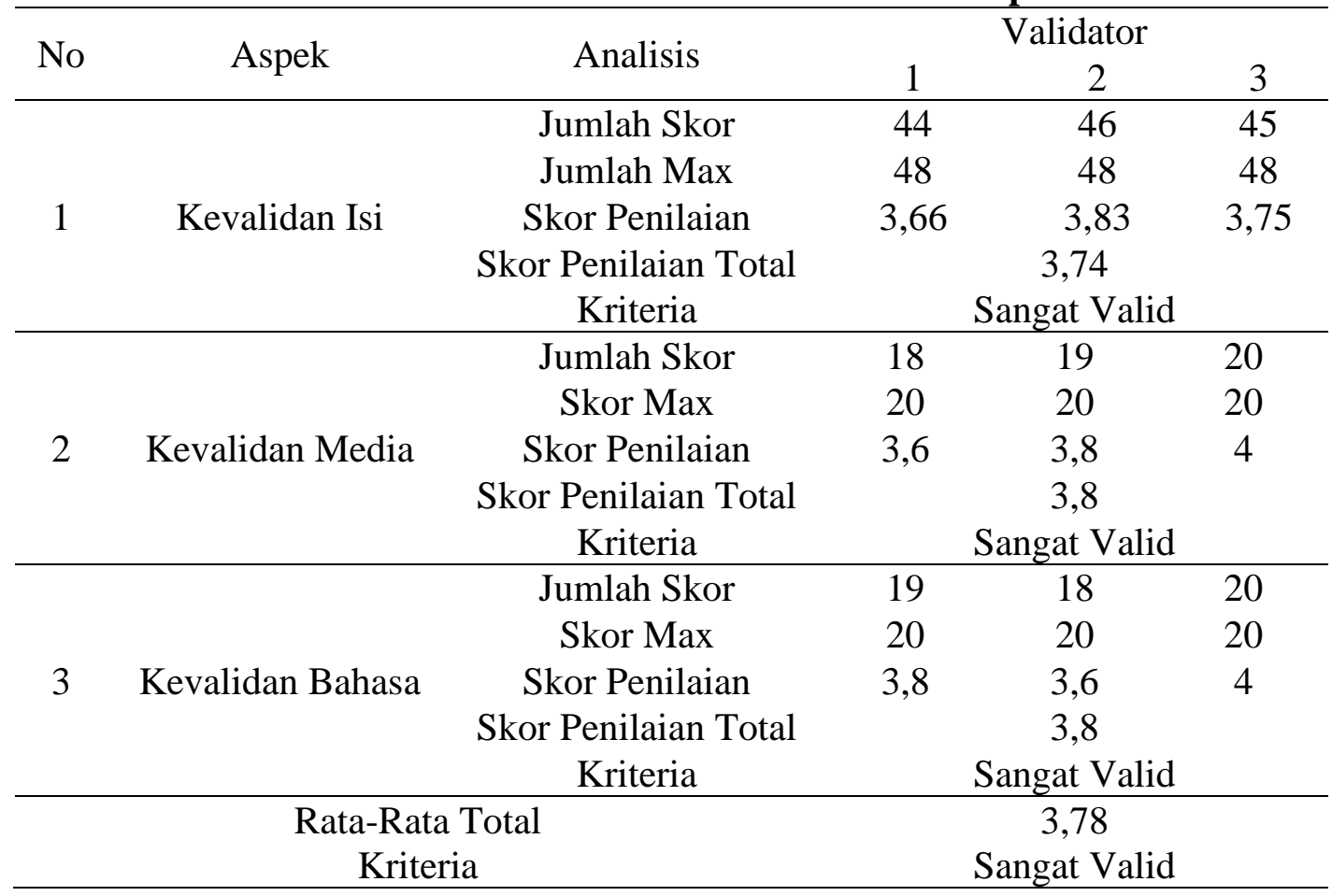

Sumber: diolah dari data penelitian, 2021

Berdasarkan Tabel 2., dapat disimpulkan bahwa e-modul berbasis sigil pada materi induksi matematika ini telah dapat diujicobakan kepada siswa sebagai media dan sumber belajar. Hal tersebut dapat terjadi dikarenakan pada setiap aspek mengalami peningkatan pada tahap uji validasi ahli materi tahap dua dan telah mendapat skor 3,78 dengan kriteria "Sangat Valid" keterangan tanpa revisi.

Selanjutnya dilakukan validasi pada produk e-modul yang sedang dikembangkan ke para ahli media. Sama halnya seperti pada validasi ahli materi, pelaksanaan validasi ahli media ini dilakukan dengan tahapan mempertimbangkan skor yang diberikan oleh validator maupun saran dan kritik terhadap e-modul. Hasil validasi ahli media tahap 1 tersaji dalam Tabel 3.

Tabel 3. Hasil Validasi Ahli Media Tahap 1

\begin{tabular}{|c|c|c|c|c|}
\hline \multirow{2}{*}{ No } & \multirow{2}{*}{ Aspek } & \multirow{2}{*}{ Analisis } & \multicolumn{2}{|c|}{ Validator } \\
\hline & & & 1 & 2 \\
\hline \multirow{5}{*}{1} & \multirow{5}{*}{$\begin{array}{l}\text { Ukuran Buku } \\
\text { Sesuai ISO }\end{array}$} & Jumlah Skor & 6 & 6 \\
\hline & & Jumlah Max & 8 & 8 \\
\hline & & Skor Penilaian & 3 & 3 \\
\hline & & Skor Penilaian Total & & \\
\hline & & Kriteria & & \\
\hline \multirow{5}{*}{2} & & Jumlah Skor & 19 & 18 \\
\hline & & Skor Max & 28 & 28 \\
\hline & Desain Sampul & Skor Penilaian & 2,71 & 2,57 \\
\hline & & Skor Penilaian Total & \multirow{2}{*}{\multicolumn{2}{|c|}{$\begin{array}{c}2,64 \\
\text { Valid }\end{array}$}} \\
\hline & & Kriteria & & \\
\hline 3 & & Jumlah Skor & 21 & 19 \\
\hline
\end{tabular}


Berdasarkan Tabel 4., dapat disimpulkan bahwa $e$-modul berbasis sigil pada materi induksi matematika ini telah dapat diujicobakan kepada siswa sebagai media dan sumber belajar. Hal tersebut dapat terjadi dikarenakan pada setiap aspek mengalami peningkatan pada tahap uji validasi ahli media tahap dua dan telah mendapatkan skor rata-rata total 3,72 dengan kriteria "Sangat Valid" keterangan tanpa revisi.

Setelah uji validasi ahli materi dan media selesai dilaksanakan maka dapat dilanjutkan dengan uji coba kelompok kecil pada kelas XI IPA 1 dengan tujuan untuk mengetahui kepraktisan dari $e$-modul berbasis sigil pada materi induksi matematika yang sedang dikembangkan. Hasil respon siswa terhadap kepraktisan e-modul berbasis sigil memperoleh skor 3,36 dengan kriteria "Sangat Praktis". kemudian dilanjutkan dengan uji coba yang lebih luas yaitu uji coba lapangan dengan tujuan untuk dapat mengetahui kepraktisan serta keefektifan dari e-modul berbasis sigil pada materi induksi matematika yang sedang dikembangkan. Hasil respon siswa terhadap kepraktisan e-modul berbasis sigil pada uji coba lapangan memperoleh skor 3,50 dengan kriteria "Sangat Praktis" dan keefektivan memperoleh persentase sebesar $82 \%$ dengan kualifikasi "Efektif". Selain itu terdapat pula uji coba yang dilakukan oleh praktisi memperloleh skor 3,57 dengan kriteria "Sangat Praktis".

Setelah desain $e$-modul berbasis sigil validasi oleh para ahli baik materi maupun media, maka dapat diketahui apa saja kelemahan-kelemahan yang terdapat dalam e-modul berbasis sigil pada materi induksi matematika. Kelemahan tersebut selanjutnya diminimalisir atau dikurangi dengan cara memperbaiki desain sesuai dengan berbagai kritik, saran dan masukkan yang telah diberikan (Sugiyono, 2017: 302). Pemilihan desain $e$-modul sendiri haruslah disesuaikan dengan gambar dan warna yang sesuai berdasarkan berbagai kritik, saran dan masukkan berbagai pihak dan hasil rujukan yang diperoleh peneliti dari berbagai sumber. Hasil revisi produk dalam penelitian ini ialah dengan cara melakukan revisi desain sesuai dengan kritik, saran serta masukan dari para ahli baik materi maupun media. Gambar 1. merupakan tampilan bagian $e$ modul hasil revisi produk yang telah dilakukan.
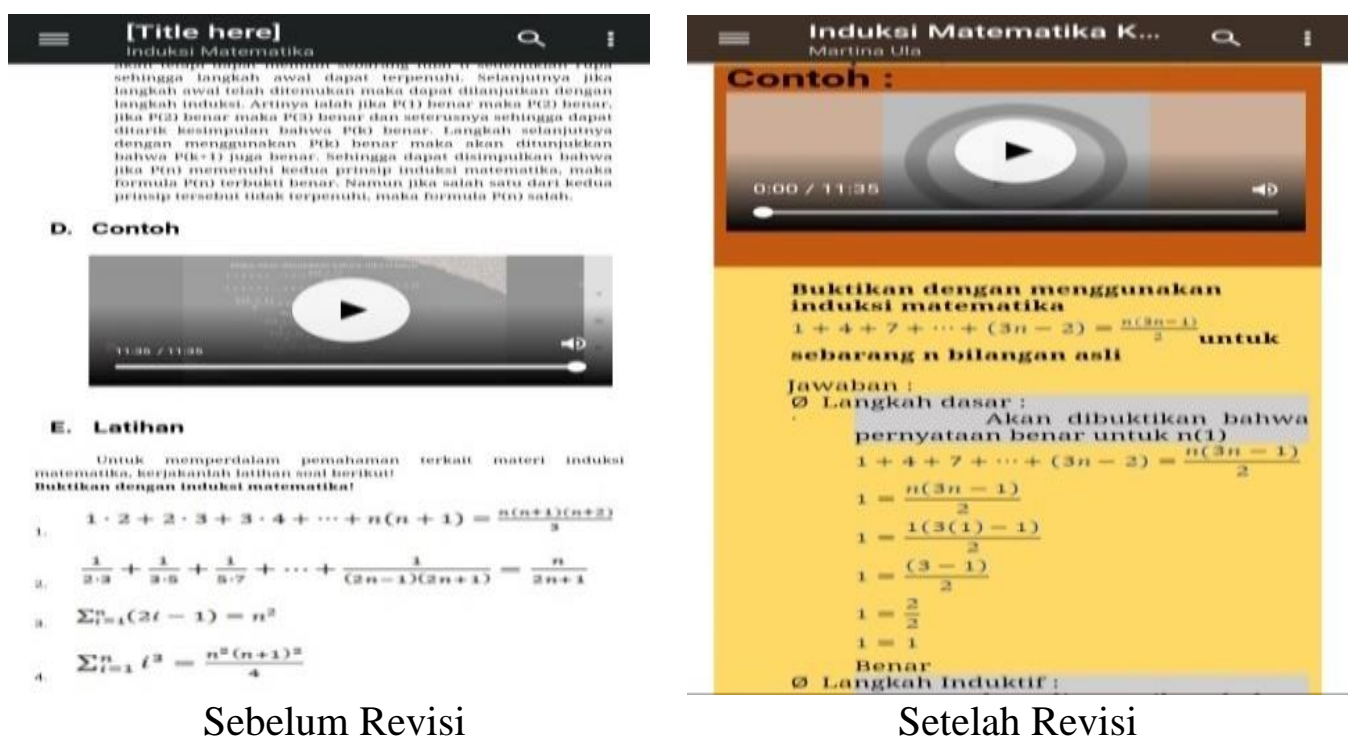

\section{Gambar 1. Tampilan Bagian E-Modul Sebelum dan Sesudah Revisi Ahli Materi}

Sebelum direvisi contoh soal yang terdapat dalam e-modul berbasis sigil pada materi induksi matematika hanya berbentuk video saja. Akan tetapi setelah direvisi contoh-contoh soal yang terdapat dalam e-modul berbasis sigil pada materi induksi matematika tidak hanya berbentuk video saja melainkan terdapat pula yang berbentuk tertulis (dapat dilihat dalam Gambar 1.). Dengan adanya berbagai macam contoh soal diharapkan siswa mampu untuk lebih memahami materi induksi matematika serta dapat dengan mudah 
mengerjakan soal-soal latihan yang telah disediakan tanpa mengalami kesulitan. Menambahkan contoh soal dalam bentuk tertulis, haruslah disajikan secara jelas, mudah dibaca dan tidak berbelit-belit dengan tujuan agar siswa mudah untuk mengerti terkait materi yang ada di dalam buku, modul atau bahkan e-modul (Ramda, 2017).

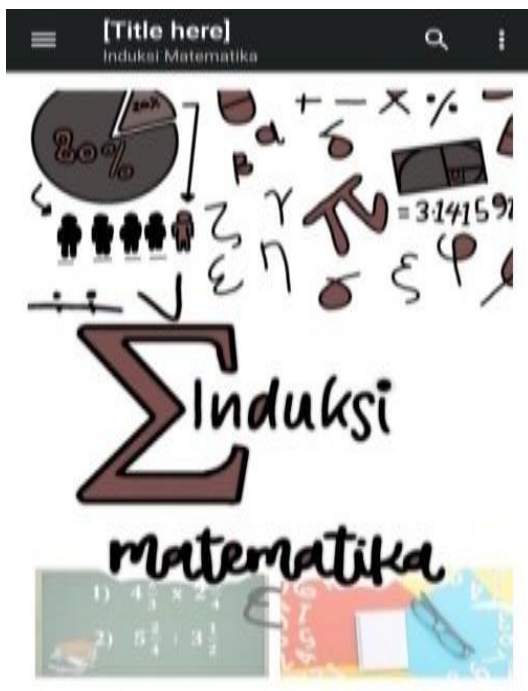

Sebelum Revisi

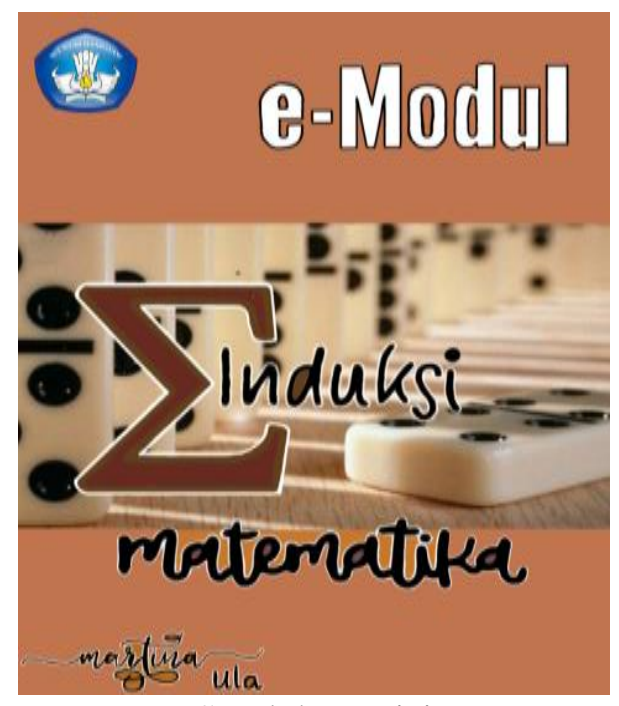

Setelah Revisi

\section{Gambar 2. Tampilan Bagian E-Modul Sebelum dan Sesudah Revisi Ahli Media}

Sebelum direvisi $e$-modul berbasis sigil pada materi induksi matematika hanya berwarna putih polos saja. Akan tetapi setelah direvisi e-modul berbasis sigil pada materi induksi matematika telah diganti menjadi warna cokelat dan kuning (seperti terlihat dalam Gambar 2.). Alasan peneliti memilih warna cokelat karena warna tersebut memiliki unsur bumi. Warna ini akan memberikan kesan hangat, nyaman serta aman. Selain itu warna cokelat secara psikologis terkesan kuat dan dapat diandalkan (Eskak et. al., 2017). Sedangkan warna kuning dipilih karena warna tersebut dapat memberikan kesan yang megah dan mewah. Selain itu warna kuning juga dapat memberikan kesan hangat dan bahagia. Secara psikologis warna kuning dapat merangsang pikiran serta mental siswa untuk dapat berpikir secara logis analitis (Adi, 2017).

Sebelum direvisi $e$-modul berbasis sigil pada materi induksi matematika tidak terdapat nama penulis. Akan tetapi setelah direvisi telah ditambahkan dengan nama penulis. Menambahkan nama penulis pada $e$ modul berbasis sigil materi induksi matematika dengan tujuan agar pembaca mengetahui penulis dari buku, modul atau e-modul tersebut (Sundari, et. al., 2020). Selain itu nama penulis juga harus ada guna meminimalisasi atau mengurangi adanya tindakan plagiasi dari pihak-pihak yang tidak bertanggung jawab.

Sebelum direvisi e-modul berbasis sigil pada materi induksi matematika pada sampul terdapat berbagai gambar yang tidak sesuai dan tidak ada kaitannya dengan materi induksi matematika. Akan tetapi setelah direvisi gambar pada sampul e-modul berbasis sigil telah sesuai dengan materi yang diangkat yaitu materi induksi matematika. Menambahkan gambar yang sesuai dengan materi induksi matematika sejalan dengan penelitian sebelumnya, adanya gambar yang menarik pada sampul buku, modul ataupun $e$-modul diharapkan mampu memberikan kesan awal yang baik agar siswa merasa tertarik untuk membaca serta mempelajari buku, modul ataupun $e$-modul yang dikembangkan (Umbaryati, 2013). Menambahkan warna pada sampul, peta konsep dan isi pada $e$-modul berbasis sigil materi induksi matematika, siswa akan lebih tertarik untuk membaca buku, modul dan e-modul yang memiliki warna, font, gambar serta ilustrasi yang tepat (Fitri, et. al., 2020). Dengan adanya warna diharapkan dapat lebih menarik perhatian siswa dalam belajar dan membaca buku, modul serta e-modul yang dikembangkan sebagai sumber ataupun media pembelajaran. 


\section{PEMBAHASAN}

Berdasarkan potensi dan masalah yang telah ditemukan melalui proses observasi serta wawancara diketahui bahwa guru belum mampu mengembangkan media atau sumber belajar seperti $e$-modul dan siswa tidak memiliki buku pegangan. Akan tetapi guru telah mampu membuat video pembelajaran ditunjang dengan siswa yang telah mempunyai laptop bahkan smartphone. Oleh karena itu agar proses pembelajaran daring dapat berjalan dengan baik dan menarik maka perlu dikembangkan sebuah media dan sumber belajar seperti $e$-modul. Pengumpulan data dalam hal ini peneliti mulai mengumpulkan data dari berbagai referensi baik jurnal, buku ataupun artikel-artikel terbaru. Pada tahap ini peneliti memilih materi induksi matematika sebagai materi yang akan dikembangkan. Kemudian memilih sigil sebagai alat bantu dalam mengembangkan e-modul tersebut. Pada tahap validasi desain dilakukan dengan cara menghadirkan beberapa ahli yaitu ahli media dan materi. Dalam hal ini terdapat tiga ahli materi dan dua ahli media yang akan memvalidasi produk e-modul berbasis sigil pada materi induksi matematika yang sedang dikembangkan. Jika masih terdapat saran, kritik, dan masukkan dari para ahli maka peneliti diharuskan untuk kembali merevisi $e$-modul tersebut dengan tujuan agar $e$-modul telah dalam keadaan yang valid untuk diberikan dan dibagikan kepada siswa (Rustaman, et. al., 2019).

Pada ahli materi dapat diketahui bahwa hasil penilaian pada tahap satu memperoleh skor 3,01 dengan kriteria "layak". Sedangkan pada tahap dua memperoleh skor 3,78 dengan kriteria "Sangat Layak". Pada ahli media pada tahap 1 memperoleh skor 2,82 dengan kriteria "Layak". Hasil penilaian validasi ahli media tahap 2 memperoleh skor 3,72 dengan kriteria "Sangat Layak". Berdasarkan hasil dari tahap 2 tersebut dapat disimpulkan bahwa $e$-modul berbasis sigil pada materi induksi matematika telah layak dan siap digunakan dalam uji coba sebagai sumber maupun media pembelajaran. Setelah validasi desain dan revisi desain telah selesai dilaksanakan. Maka langkah selanjutnya ialah dengan melakukan uji coba produk. Dalam penelitian ini dilakukan dua kali uji coba produk yaitu uji coba kelompok kecil pada kelas XI IPA 1 dengan jumlah siswa 10 orang sebagai wakil populasi kelas tersebut dan uji coba lapangan pada kelas XI IPA 2 dengan jumlah siswa 28 orang.

Hal tersebut sesuai dengan penelitian yang sudah dilakukan sebelumnya, jika $e$-modul pembelajaran telah dinyatakan valid dan siap dari hasil uji validasi ahli materi, maka sumber atau media pembelajaran tersebut dapat digunakan dalam kegiatan proses belajar mengajar dengan artian diujicobakan kepada siswa baik dalam skala kecil maupun besar (Tania \& Susilowibowo, 2017). Hal ini sejalan dengan penelitian lainnya, sebuah sumber atau media pembelajaran dapat digunakan pada proses pembelajaran apabila telah dinyatakan valid baik oleh ahli materi maupun media (Herawati \& Muhtadi, 2018).

Selain uji kepraktisan diadakan juga uji keefektifan yang dilakukan dengan cara memberikan soal tes kepada siswa kelas XI IPA 2. Sebelum memberikan tes terlebih dahulu diadakan pembelajaran sebanyak tiga kali pertemuan dengan menggunakan $e$-modul berbasis sigil pada materi induksi matematika. Soal tes diberikan pada pertemuan ke-tiga di akhir proses kegiatan belajar mengajar. Soal tes yang diberikan sebanyak 4 butir dengan bentuk soal isian. Hasil dari uji Keefektifan memproleh persentase sebesar 82\% dengan kualifikasi "Efektif". Dikarenakan hasil pada uji kelompok kecil serta lapangan telah mencapai kriteria "Sangat Praktis" dan pada uji keefektifan juga memperoleh kriteria efektif dengan skor persentase $82 \%$ maka, tidak perlu diadakan revisi dan dapat dinyatakan telah valid digunakan sebagai media serta sumber belajar. Pada penelitian lain disebutkan, suatu produk dapat dikatakan efektif jika banyaknya siswa telah melampaui Kriteria Ketuntasan Minimum (KKM) sudah lebih dari batas yang ditetapkan dalam sebuah penelitian (Meliana, 2020).

E-modul berbasis sigil pada materi induksi matematika yang dikembangkan berisi materi, gambar dan juga video agar siswa dapat belajar secara mandiri walaupun pembelajaran dilaksanakan secara daring 
(dalam jaringan). Hal tersebut sejalan dengan penelitian terdahulu, $e$-modul berbasis sigil dapat berisi teks, gambar bahkan video dengan harapan agar siswa mampu memahami serta mereview kembali materi-materi yang telah dipelajari sebelumnya dengan baik (Rustaman, et. al., 2019). Selain itu, e-modul berbasis sigil memiliki banyak kelebihan yaitu praktis dan mudah untuk digunakan sebagai sarana untuk membuat atau mengembangkan sebuah $e$-modul yang akan digunakan sebagai sumber atau media pembelajaran (Aisy, et. al., 2020). E-modul berbasis sigil ini didukung oleh banyak perangkat seperti komputer, laptop dan smartphone sehingga dapat dengan mudah diakses melalui google chrome dan plugin firefox. Pada Microsoft windows, Apple macos dan linux dapat menggunakan perangkat lunak seperti yaitu caliber ebook viewer, azardi. Sedangkan melalui android dengan menggunakan ideal reader, FBReaderO, iOS (ireader), blackberry playbook, sony reader. E-modul pembelajaran matematika berbasis sigil dapat diakses secara gratis pada laptop dapat menggunakan aplikasi Azardi, sedangkan pada smartphone dapat menggunakan aplikasi Reasily.

E-modul berbasis sigil pada materi induksi matematika ini memiliki kelebihan dan kekurangan. Kelebihan dari $e$-modul berbasis sigil: a) memuat materi induksi matematika yang sesuai dengan kurikulum 2013 ; b) sangatlah mudah diaplikasikan karena dapat dibuka melalui laptop bahkan smartphone dan tidak memerlukan koneksi internet untuk membukanya; c) sangatlah mudah untuk dipahami sehingga siswa tidak kebingungan saat menggunakannya; d) terdapat materi, contoh soal baik dalam bentuk video maupun tertulis, serta adanya latihan-latihan soal yang dapat dikerjakan oleh siswa. Sedangkan kekurangan dari $e$ modul berbasis sigil: a) materi yang disajikan baru sebatas induksi matematika; b) memerlukan bantuan dari aplikasi lainnya agar $e$-modul berbasis sigil dapat dibuka baik melalui laptop maupun smartphone

Namun demikian, e-modul berbasis sigil berdasarkan penelitian-penelitian yang sudah dilakukan, dapat memberikan dampak yang positif terhadap proses pembelajaran. Penelitian menunjukkan $e$-modul berbasis sigil yang dikembangkan untuk mendukung proses belajar mengajar secara langsung maupun tidak langsung valid, praktis dan efektif untuk digunakan dalam kegiatan pembelajaran di sekolah (Wirasasmita \& Uska, 2017). Selain itu, e-modul yang dibuat dengan menggunakan sigil terlihat sangat bagus baik dengan menggunakan smartphone maupun dengan menggunakan laptop (Hasbiyati \& Khusnah, 2016). E-modul berbasis sigil yang telah dinyatakan valid, praktis dan efektif ini juga cocok untuk dijadikan sebagai media dan sumber belajar bagi siswa. Pada akhirnya penelitian ini dikuatkan juga oleh penelitian yang telah dihasilkan sebelumnya, meskipun dalam $e$-modul berbasis sigil memiliki banyak kekurangan akan tetapi $e$ modul ini sangatlah efektif jika digunakan untuk melatih dalam berpikir kritis dan mampu meningkatkan minat membaca siswa (Amalia \& Kustijono, 2017).

\section{SIMPULAN}

Hasil dari angket validasi ahli materi memperoleh skor 3,01 dengan kriteria "Layak" dan ahli media memperoleh skor 2,82 dengan kriteria "Layak" pada tahap satu. Sedangkan pada tahap dua ahli materi memperoleh skor 3,78 dengan kriteria "Sangat Layak" dan ahli media memperoleh skor 3,72 dengan kriteria "Sangat Layak". Maka dapat disimpulkan bahwa $e$-modul berbasis sigil pada materi induksi matematika ini telah sangat layak untuk diujicobakan kepada siswa serta dapat digunakan sebagai media ataupun sumber pembelajaran. Hasil dari respon siswa mengenai kepraktisan dari e-modul berbasis sigil materi induksi matematika pada uji coba kelompok kecil memperoleh skor 3,36 dengan kriteria "Sangat Praktis". Sedangkan pada uji coba lapangan respon siswa memperoleh skor 3,50 dengan kriteria "Sangat Praktis". Selain repson siswa terdapat pula respon guru terhadap kepraktisan dari e-modul berbasis sigil materi induksi matematika yang memperoleh skor 3,57 dengan kriteria "Sangat Praktis". Hasil uji keefektivan yang dilaksanakan di kelas XI IPA 2 memperoleh persentase sebesar 82\% dengan kualifikasi "Efektif". Adanya penilitian ini dapat menambah khasanah pengetahuan baru dalam proses belajar mengajar di kelas, 
dikarenakan e-modul berbasis sigil dapat digunakan secara offline atau luar jaringan, serta keefektivan belajar siswa sangat tinggi. Guru dapat memanfaat $e$-modul ini untuk menambahkan materi-materi terbaru dengan sangat mudah.

\section{DAFTAR RUJUKAN}

Adi, G. B. (2017). Dampak penggunaan warna panas dalam upaya branding suatu produk. PRODUCTUM: Jurnal Desain Produk (Pengetahuan Dan Perancangan Produk), 3(2), 58. https://doi.org/10.24821/productum.v3i2.1623

Agustina, L., \& Rusmana, I. M. (2020). Pembelajaran Matematika Menyenangkan dengan Aplikasi Kuis Online Quizizz. Prosiding Sesiomadika, Seminar Nasional Matematika Dan Pendidikan Matematika, 2(1a), 1-7. https://journal.unsika.ac.id/index.php/sesiomadika/article/view/2249

Aisy, D. R., Farida, \& Andriani, S. (2020). Pengembangan E-modul Berbantuan Sigil Software Dengan Pendekatan Saintifik Pada Materi Sistem Persamaan Linier Dua Variabel ( SPLDV ). EduSains: Jurnal Pendidikan Sains \& Matematika, 8(1), 61-71. https://doi.org/https://doi.org/10.23971/eds.v8i1.1499

Amalia, F., \& Kustijono, R. (2017). Efektifitas Penggunaan E-Book Dengan Sigil untuk Melatihkan Kemampuan Berpikir Kritis. Prosiding Seminar Nasional Fisika (SNF), 1, 81-85.

Anawati, Y., Ula, M., \& Susilo, G. (2020). Pembelajaran E-Learning dalam Membantu Pemecahan Soal High Order Thinking Skill di Tengah Pandemi Covid - 19. Prosiding Diskusi Panel Nasional Pendidikan Matematika, 159-168. http://proceeding.unindra.ac.id/index.php/DPNPMunindra/article/view/4734

Angga, R., Sri, R., \& Intan, B. (2019). Pengembangan Metode HARUM PALA (Hafalan Rumus Pakai Lagu) pada Siswa Sekolah Menengah Pertama di Balikpapan. PRISMA, Prosiding Seminar Nasional Matematika, 2, 84-98. https://journal.unnes.ac.id/sju/index.php/prisma/article/view/28876

Darma, R. S., Setyadi, A., Wilujeng, I., Jumadi, J., \& Kuswanto, H. (2019). Multimedia Learning Module Development based on SIGIL Software in Physics Learning Multimedia Learning Module Development based on SIGIL Software in Physics Learning. Journal of Physics: Conference Series PAPER, 1233, 1-7. https://doi.org/10.1088/1742-6596/1233/1/012042

Eskak, E., Salma, I. R., \& Sumarto, H. (2017). Peningkatan kecerahan dan daya rekat warna pada produk gerabah batik. PRODUCTUM: Jurnal Desain Produk (Pengetahuan Dan Perancangan Produk), 3(1), 1. https://doi.org/10.24821/productum.v3i1.1733

Faizin, K. (2020). Analisis Penggunaan Metode Penelitian Evaluasi pada Penelitian Bahasa Arab Model Pengembangan. Tabyin: Jurnal Pendidikan Islam, 02(01), 39-53. https://doi.org/https://doi.org/10.29138/tabyin.v2i1.27

Fitri, H. R., Mufit, F., \& Asrizal, A. (2020). Validitas dan Praktikalitas Bahan Ajar Fisika Materi Kalor dan Teori Knetik Gas Mengintegrasikan Literasi Baru dan Literasi Bencana Untuk Kleas XI SMA. Pillar Of Physics Education, 13(1), 169-176.

Hasbiyati, H., \& Khusnah, L. (2016). Pengembangan E-book Bereksistensi EPUB Pada Pembelajaran IPA SMP. Bioshell, 5(01), 298-305.

Herawati, N. S., \& Muhtadi, A. (2018). Pengembangan Modul Elektronik (E-modul) Interaktif Pada Mata Pelajaran Kimia Kelas XI SMA. Jurnal Inovasi Teknologi Pendidikan, 5(2), 180-191.

Istikomah, I., Purwoko, R. Y., \& Nugraheni, P. (2020). Sigil: Pengembangan Modul Elektronik Berbasis RME pada Materi Lingkaran untuk Siswa SMP. Jurnal Penelitian Pendidikan Dan Pengajaran Matematika, 6(2), 91-98. https://doi.org/10.37058/jp3m.v6i2.1957

Kamal, M. (2020). Research and Development (R\&D) Tadribat/Drill Madrasah Aliyah Class X Teaching Materials Arabic Language. Santhet: Jurnal Sejarah, Pendidikan Dan Humaniora, 4(1), 10-18. 
https://doi.org/10.36526/js.v3i2.e-ISSN

Meliana, W. (2020). Pengembangan E-modul Format EPUB Untuk Pembelajaran Matematika Kelas X Pada Materi Trigonometri. Jurnal PTK \& Pendidikan, 6(1). https://doi.org/DOI:10.18592/ptk.v6il.3778

Mulyati, S., \& Evendi, H. (2020). Pembelajaran Matematika Melalui Media Game Quizizz untuk Meningkatkan Hasil Belajar Matematika SMP 2 Bojonegara. GAUSS: Jurnal Pendidikan Matematika, 03(01), 64-73. https://doi.org/http://dx.doi.org/10.30656/gauss.v3il.2127

Mulyatna, F., Imswatama, A., \& Rahmawati, N. D. (2021). Design Ethnic-Math HOTS: Mathematics Higher Order Thinking Skill Questions Based On Culture and Local Wisdom. Malikussaleh Journal of Mathematics Learning (MJML), 4(1), 48. https://doi.org/10.29103/mjml.v4i1.3059

Nirfayanti, \& Nurbaeti. (2019). Pengaruh Media Pembelajaran Google Classroom Dalam Pembelajaran Analisis Real Terhadap Motivasi Belajar Mahasiswa. Jurnal Penelitian Matematika Dan Pendidikan Matematika, 2(1), 50-59. https://doi.org/https://doi.org/10.30605/2615-7667.211

Ramda, A. H. (2017). Analisis Kesesuaian Materi pada Buku Teks Matematika Kelas VII dengan Kurikulum 2013. PYHTAGORAS: Jurnal Matematika Dan Pendidikan Matematika, 12(1), 12-22. https://doi.org/https://doi.org/10.21831/pg.v12i1.14057

Rustaman, A. H., Iqbal, M., \& Amelia, W. (2019). Pengembangan Modul Digital Praktikum Komputer Grafis 1 Dalam Format Elektronik Publication (EPUB) Untuk Meningkatkan Pemahaman Teknik Grafis Mahasiswa Desain Komunikasi Visual (Topik: Digital Imaging). JISIP, 3(1), 224-229. https://doi.org/http://dx.doi.org/10.36312/jisip.v3i1.647

Rusydi, I. (2020). Pemanfaatan Perpustakaan Sebagai Sumber Belajar Mahasiswa Fakultas Agama Islam Universitas Wiralodra Tahun Akademik 2019/2020. Jurnal Risalah (Jurnal Pendidikan Dan Studi Islam), 6(1), 258-269. https://doi.org/https://doi.org/10.31943/jurnal_risalah.v6i2.160

Sasmita, R. S. (2020). Pemanfaatan Internet Sebagai Sumber Belajar. Jurnal Pendidikan Dan Konseling, 2(1), 99-103. https://doi.org/https://doi.org/103.31004/jpdk.v1i2.603

Sugiyono, S. (2017). Metode Penelitian Kuantitatif, Kualitatif dan R\&D. Bandung: Alfabeta.

Sundari, R., Karyono, T., \& Soeteja, Z. S. (2020). Pengembangan Buku Pengayaan Bermuatan Lokal Bagi Mahasiswa PGSD. MUALLIMUNA: Jurnal Madrasah Ibtidaiyah, 6(1), 27-39. https://doi.org/http://dx.doi.org/10.31602/muallimuna.v6i1.3334

Tania, L., \& Susilowibowo, J. (2017). Pengembangan Bahan Ajar E-modul Sebagai Pendukung Pembelajaran Kurikulum 2013 Pada Materi Ayat Jurnal Penyesuaian Perusahaan Jasa Siswa Kelas X Akuntansi SMA Negeri 1 Surabaya. JPAK: Jurnal Pendidikan Akuntansi, 5(2), 1-9.

Tobing, H. E. L., Somakim, S., \& Susanti, E. (2020). The Use of Electronic Modules Designed Using Sigil in Learning the Distance in Geometry. Advances in Social Science, Education and Humanities Research, 513, 640-647. https://doi.org/https://doi.org/10.2991/assehr.k.201230.175

Umbaryati, U. (2013). Pentingnya LKPD pada Pendekatan Scientific Pembelajaran Matematika. PRISMA, Prosiding Seminar Nasional Matematika, 1(1), 217-225.

Wahyudi, D. (2019). Pengembangan E-modul Dalam Pembelajaran Matematika SMA Berbasis Android ( Development Of E-Modules In Learning Math High School Android Based). Gauss: Jurnal Pendidikan Matemaika, 02(02), 1-10. https://doi.org/http://dx.doi.org/10.30656/gauss.v2i2.1739

Widyastuti, R. (2015). Proses Berpikir Siswa dalam Menyelesaikan Masalah Matematika Berdasarkan Teori Polya Ditinjau dari Adversity Quotient Tipe Climber. Al-Jabar: Jurnal Pendidikan Matematika, 6(2), 183-193. https://doi.org/https://doi.org/10.24042/ajpm.v6i2.48

Wirasasmita, R. H., \& Uska, M. Z. (2017). Pengembangan Media Pembelajaran Berbasis Buku Digital Elektronic Publication (EPUB) Menggunakan Software Sigil pada Mata Kuliah Pemrograman Dasar. EDUMATIC: Jurnal Pendidikan Informatika, 1(1), 11-16. https://doi.org/https://doi.org/10.29408/edumatic.v1i1.732 
14 Ula, Susilo, \& Permatasari

Wiratomo, Y., \& Mulyatna, F. (2020). Use of Learning Management Systems in Mathematics Learning during a Pandemic. Journal of Mathematical Pedagogy (JoMP), 1(2), 62-71. https://doi.org/https://doi.org/10.26740/jomp.v1n2.p\%25p 